$10(1)(2021) 34-40$
Unnes Science Education Journal
Accredited Sinta 3 3

\title{
Real Science Mask with QR Code to Improve The Digital Literation
}

\author{
Erna Noor Savitri ${ }^{\bowtie}$, Novi Ratna Dewi, Andin Vita Amalia, Oky Eviana Putri Rahmadani, \\ Anisia Kholidah
}

DOI: http://dx.doi.org/10.15294/usej.v10i1.42537

Department of Integrated Science, Faculty of Mathematics and Natural Sciences,

Universitas Negeri Semarang, Indonesia

\section{Article Info}

Submitted 11 November 2020

Accepted 17 February 2021

\section{Keywords}

Real Science Mask, QR Code, Digital Literation Revised 28 December 2020

\begin{abstract}
This research aims to develop a valid Real Science Mask with QR Code learning media. The goal to be achieved through this research in general is to produce learning media that can build a concrete learning experience and be able to improve digital literacy of science students. The research and development $(\mathrm{RnD})$ method by analysis, design, development, implementation, and evaluation (ADDIE) was performed. The data collection instruments used were observation sheets, expert validation sheets, and questions. The teaching and learning instruments were declared feasible and ready for application with a few revisions based on the validation results. Aspects that are considered in the feasibility test of the Real Science Mask with QR Code media are relevance, efficiency, effectiveness, flexibility, interface, suitability of material with digital and cognitive literacy skills, and media function. Real Science Mask with QR Code is a specially designed learning media that has been tested feasible and valid to improve digital literacy of science students.
\end{abstract}

\section{How to Cite}

Savitri, E. N., Dewi, N. R., \& Amalia, A. V. (2021). Real Science Mask with QR Code to Improve The Digital Literation. Unnes Science Education Journal, 10(1), 3440.

Correspondence Author:

E-mail: ernanoors@mail.unnes.ac.id

p-ISSN 2252-6617

e-ISSN 2502-6232 


\section{INTRODUCTION}

The Industrial Revolution 4.0 demands the use of technology in every aspect, including education. Therefore, Indonesia must strive to improve readiness to face the Industrial Revolution 4.0 in terms of Human Resources (HR) and infrastructure so that it can compete with other countries. One of the efforts to prepare human resources in the field of education is the existence of a government policy regarding "Free Learning: Independent Campus". This aims to create a learning culture that is innovative, non-restrictive, and in accordance with the needs of each university. A non-restrictive learning culture means that learning is not limited to one area of expertise and learning can be done anywhere and anytime. Higher education graduates will be required to be able to master various fields of science and be flexible in developing independence in seeking and finding knowledge. This requires good digital literacy skills. Digital literacy is the interest, attitude and ability of individuals in using digital technology and communication tools to access, manage, integrate, analyze and evaluate information, build new knowledge, create and communicate with others in order to participate effectively in society (Kurniawati \& Baroroh, 2016).

The development of information technology allows the production of interactive multimedia in learning that facilitates and arouses student motivation. At this time, computer-based interactive multimedia was developed with the use of computers as a guide (computer assisted instruction). The rapid development of technology and information today makes it possible for teachers to design learning that can minimize teacher attendance. The teacher as a facilitator can construct computer-based learning that can be done independently by students. Through computer-based interactive media students immediately receive feedback via a computer and exercises can be repeated according to students' abilities. Interactive learning media with computer guides involve users in activities that require mental processes in learning (Hutagalung, 2013). Digital-age in the world of education, especially in higher education, has consequences in the form of learning designs by utilizing digital media as a means to increase student knowledge. Digital media can present learning material in a contextual, audio and visual way in an interesting and interactive manner (Umam et al. in Setyaningsih et al., 2020).

Learning media is an integral part of the learning system. Many kinds of learning media can be used. Its use includes many benefits. The use of learning media must be based on the right selection, so that it can increase the meaning and function in supporting the effectiveness and efficiency of the learning process. Learning media can also be interpreted as anything that can be used to transmit messages, stimulate thoughts, feelings, attention, and the willingness of students so that they can encourage the learning process. Forms of learning media are used to enhance the learning experience so that it becomes concrete. Learning using learning media is not just using words (verbal symbols so as to produce a more meaningful learning experience for students (Asyhari \& Silvia, 2016). Real Science Mask with QR Code is a learning media in the form of a mask containing illustrations of science material connected to google classroom. Its use is expected to make concrete a science concept. In addition, its use that is connected to google classroom can provide unlimited access in the learning process so that learning can be done anywhere and anytime. Applied research for the development of Real Science Mask with QR Code which is expected to be a solution to build a concrete learning experience and be able to improve digital literacy of science students. The applied research proposed is in accordance with the 2016-2020 UNNES Research Strategic Plan, namely increasing the benefits of science and technology for the surrounding community through Tridharma activities. This research is also in line with one of the pillars of UNNES conservation, namely the pillars of value and character because the research carried out has innovative values in learning and is paperless. The specific objective to be achieved in this research is to produce learning media that is tested valid, feasible in terms of readability and graphics and has been tested for its effective use in improving digital literacy of science students.

Science is a collection of concepts, facts and principles which constitute an invention. IPA is a dynamic process for seeking knowledge through searching, investigating, and verifying (Metaputri \& Garminah, 2017). Science is an abstract science for students so that in achieving science learning, students must go through a good learning process. An innovative model is needed to facilitate students to be actively involved in the learning process and carry out a dynamic science process to achieve learning goals.

Based on the background described, the researcher aims to develop a valid Real Science Mask with QR Code learning media. The goal to be achieved through this research in general is to produce learning media that can build a con- 
crete learning experience and be able to improve digital literacy of science students. A research on digital literacy was conducted by Murray and Perez (2014) which was conducted on final year students at regional universities in the United States, which stated that understanding of digital literacy cannot be equated with the level of exposure and interaction of students with digital technology on a daily basis, the results of literacy assessments digital shows that only $12 \%$ of students can answer about $80 \%$ of the answers correctly. This shows that although basically students have often interacted with digital technology, it does not mean that they have a good understanding of digital literacy, so it is necessary to develop a strategy to increase digital literacy for students that is coherent, inclusive and holistic (Murray and Perez, 2014)

ICT-based and conventional-based have been done before. Fatimah \& Mufti (2014), have developed Android-Based Smartphone SciencePhysics Learning Media. Permana et al. (2014) has developed Multimedia-based Science Learning Media. Mulyadi et al. (2016) has created Flipbook Flash Media. Rahman et al. (2017) has made Android Based Augmented Reality. These studies still only focus on learning outcomes. In its development, researchers adopted the importance of digital literacy in the face of the Industrial Revolution 4.0 in education. The results of research that take the theme of digital literacy have been carried out by several researchers, including research on increasing digital literacy that can be done using the Technology-Embedded Scientific Inquiry (TESI) Learning Model (Nurcahyo, 2016). In addition, there are also studies that use the Science Technology Society learning model to determine its effect on science learning outcomes in terms of digital literacy (Jayanti et al., 2019). Science literacy can be trained using Schoology-based e-learning (Misbah et al., 2018). The use of website-based learning media can also improve students' digital literacy skills in learning physics (Rahayu et al., 2019). The applied research that will be carried out also utilizes IT-based learning media (technology).

The learning media used is the Real Science Mask with QR Code, in the form of a mask containing illustrations of science material connected to google classroom. Real Science Mask with QR Code as a learning media specially designed to improve digital literacy of science students. Research on the use of science masks linked to QR codes has never been conducted. The research activity is divided into 2 stages, namely: 1) making Real Science Mask with QR Code validated by experts and learning tools that have been tested for legibility, 2) testing the use of Real Science Mask with QR Code in learning to see the effectiveness in improving students' digital literacy IPA accompanied by a description of device development.

Literacy is not just reading or writing but digital literacy is the knowledge and skills to use digital media, communication tools, or networks in finding, evaluating, using, making information and utilizing it in a healthy, wise, intelligent, accurate, precise and obeying laws in order to foster communication and interaction in everyday life (Mauludin \& Cahyani, 2018). In Indonesia itself, there have not been many studies examining this digital literacy. Previous research has mainly examined information literacy, media literacy and ICT literacy in a particular group of people in several regions in Indonesia. Digital literacy competencies are useful for dealing with information from various digital sources that continue to develop along with the development of information and communication technology as a result of the phenomenon of media convergence (A'yuni, 2015).

\section{METHOD}

This research is classified as research and development $(\mathrm{RnD})$ method by analysis, design, development, implementation, and evaluation (ADDIE) was performed. The device being developed is the Real Science Mask with QR Code Learning Media, which is connected to the google classroom through the QR Code. The research instruments included the learning media expert validation sheet, the learning material expert validation sheet, the validation sheet from the digital literacy observation sheet, and the student response questionnaire to the use of learning media and the learning process. The research variables carried out were the response of material experts, linguists and IT experts and material experts (learning media) to the learning tools developed, digital literacy of science students, and science student responses, indicators of feelings, opinions, student interest in learning components and student opinions. about learning media and the learning process.

The development procedure uses Borg and Gall's theory (Emzir (2010: 271), namely (a) analysis of the product to be developed; (b) developing the initial product; (c) expert validation and revision; (d) legibility and revision testing; (e) limited use / field trials. The steps of the research can be seen in Figure 1. 


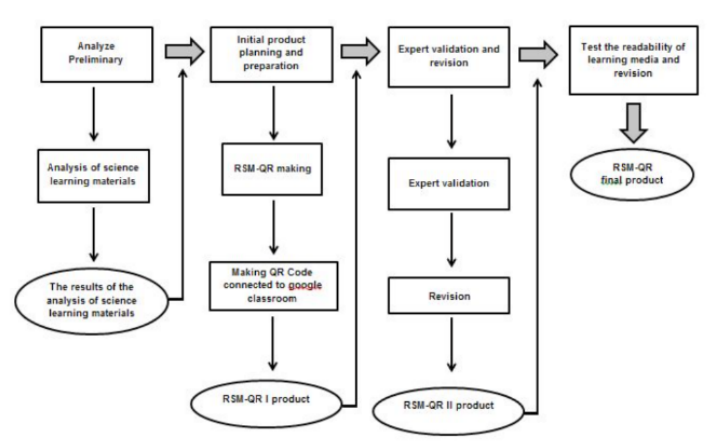

Figure 1. Steps of The Research

The initial stage of the research carried out a preliminary analysis of the science learning material in the Science Education Study Program of the Integrated Science Department of the UNNES Even Semester 2019/2020 which was already there in terms of the media used and the impact that students had from the use of existing learning media. The next stage is the design and preparation of the initial product.

Activities carried out at this planning stage are the creation of a Real Science Mask with QR Code (RSM-QR) which has been adjusted to the characteristics of the science learning material and connects it with google classroom. Activities carried out in succession, namely: (a) expert assessment, (b) Revision. Experts / validators selected in this stage are experts in the field of material and media. Material experts are needed to obtain input regarding the material content presented in learning media. Meanwhile, media experts are needed so that the learning media used can facilitate students in learning. Input from the validators was carried out to revise the RSM-QR I to RSM-QR II. The data analysis was carried out successively by: (a) Collecting data about the assessment and input / suggestions for improvement from the validators; (b) Conduct a description of the results of the general assessment of the validators; (c) Select and consider various corrections and suggestions for improvement from the validators. Readability test using 10 students. The purpose of this study was to produce valid learning media based on expert validation and tested feasible in terms of readability, then data analysis was carried out descriptively to produce information that could be used to revise RSMQR II into Final Products.

Test the use of learning media that has been made, using 1 class. Testing the use of the Real Science Mask with QR Code which is expected to be a solution to build a concrete learning experience and be able to improve digital literacy of science students. The data collection technique is done by observing using observation sheets that have been made and have been adjusted to the digital literacy indicator.

The population used in this study were all students of the Science Education Study Program of the Integrated Science Department of FMIPA UNNES in the even semester of the 2019/2020 school year, while the samples used were students of the Integrated Science Education Study Program, $4^{\text {th }}$ semester. The results of the observation data were then analyzed to obtain. the literacy profile of science students with high, medium and low abilities. The implementation of this usage test will be carried out in the even semester by involving 3 lecturers as the implementing team, 2 students and 1 IT staff. All data were in the form of: responses, comments and suggestions from students and observers as well as several important events during the implementation were recorded and then analyzed descriptively.

The data collection technique was carried out using the following methods: (a) Documentation, is used to obtain an evaluation of existing / prior learning media as well as initial data to determine the experimental and control classes; (b) Observations used to obtain digital literacy of science students during learning; (c) Questionnaire, is used to obtain data about the responses of science students to the learning media developed and the ongoing learning; (d) Test, is used to obtain data on student achievement in terms of mastery of the material; (e) Interview, is used to support digital literacy data.

\section{RESULT AND DISCUSSION}

The Real Science Mask with QR Code that has been made is then validated by 4 lecturers and 1 teacher to validate its legibility. The making of Real Science Mask with QR Code was revised 3 times with the addition of input from experts. The following is a picture of the mechanism for using Real Science Mask with QR Code as a learning media:

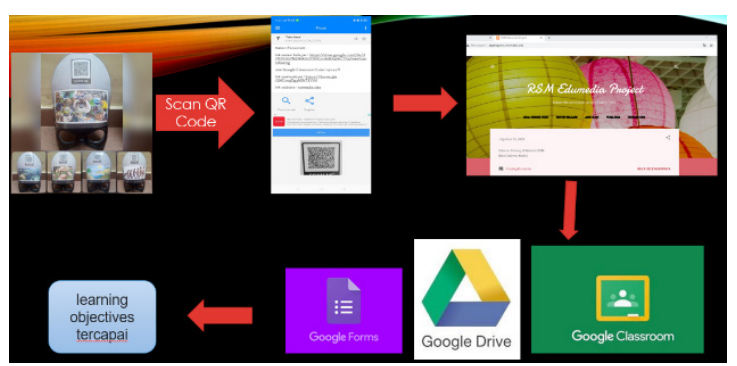

Figure 2. Using Real Science Mask with QR Code as a learning media 
The validators for the feasibility test of the Real Science Mask with QR Code media were obtained with 4 experts and 1 teacher. The names of the five experts can be seen in Table 1 .

Table 1. Validators

\begin{tabular}{ll}
\hline Name & Institution \\
\hline Arif Widiyatmoko, S. Pd., M. Pd., & Lecturer \\
Ph.D. & \\
Riza Arifudin, S. Pd., M. Cs. & Lecturer \\
Muhamad Taufiq, S. Pd., M. Pd. & Lecturer \\
Prasetyo Listiaji, S.Pd., M.Sc. & Lecturer \\
Almira Yasmin, S.Pd. & Teacher \\
\hline
\end{tabular}

Aspects that are considered in the feasibility test of the Real Science Mask with QR Code media are relevance, efficiency, effectiveness, flexibility, interface, suitability of material with digital and cognitive literacy skills, and media function. A summary of the results of the media feasibility test is shown in Table 2 .

Based on Table 2, it is found that the average total assessment of what percentage is $85.33 \%$ and which category is very appropriate (feasible to use). The input of experts is written directly on the validation sheet provided. Overall, and each aspect has met the very proper criteria, however, there are still some suggestions from experts that need to be considered for the perfection of the media. Input by experts can be seen in Table 3 .

Based on input from the validator, revisions were made, both in the Real Science Mask with QR Code media and the appearance of the website. The results of research that take the theme of digital literacy have been carried out by several researchers, including research on increasing digital literacy that can be done using the Technology-Embedded Scientific Inquiry (TESI) Learning Model (Nurcahyo, 2016). In addition, there is also research that uses the Science Technology Society learning model to determine

Table 2. Media Feasibility Test Results

\begin{tabular}{lccccccc}
\hline \multirow{2}{*}{ Aspect } & \multicolumn{4}{c}{ Validators } & Average & Result \\
\cline { 2 - 8 } & P1 & P2 & P3 & P4 & P5 & \\
\hline Relevance of Media & 100 & 80 & 100 & 80 & 100 & 92 & Very Appropriate \\
Media Efficiency & 80 & 60 & 100 & 80 & 80 & 80 & Appropriate \\
Media Effectiveness & 100 & 80 & 80 & 80 & 80 & 84 & Very Appropriate \\
Implementation & 100 & 80 & 80 & 100 & 80 & 88 & Very Appropriate \\
Flexibility & 80 & 40 & 80 & 80 & 80 & 72 & Appropriate \\
Media Interface & 100 & 100 & 80 & 80 & 100 & 92 & Very Appropriate \\
Suitability of material with & 100 & 80 & 80 & 80 & 100 & 88 & Very Appropriate \\
digital literacy & & & & & & & \\
The suitability of media with & 80 & 60 & 100 & 80 & 80 & 80 & Appropriate \\
logical thinking skills & 100 & 80 & 100 & 100 & 80 & 92 & Very Appropriate \\
Media function & 93,33 & 73,33 & 89 & 84,44 & 86,67 & 85,33 & Very Appropriate \\
Average results & & & & & & & \\
\hline
\end{tabular}

Table 3. Review and Media Revision Results

\begin{tabular}{|c|c|}
\hline Review & Revision \\
\hline The media material is made thicker and stronger. & $\begin{array}{l}\text { The media material is made using acrylic and } \\
\text { plastic materials to make it stronger }\end{array}$ \\
\hline Images with source or made by yourself & $\begin{array}{l}\text { Images taken over the internet are supplied with } \\
\text { the source and some are personal image collec- } \\
\text { tions of the author }\end{array}$ \\
\hline Not too many types of fonts are used & Use the same 2 fonts \\
\hline Web appearance can be made more attractive & The web interface has been adjusted to the user \\
\hline Material is not just text & Adding material in the form of learning videos \\
\hline Web page tailored for HP or laptop users & $\begin{array}{l}\text { The display of web pages is flexible for laptop } \\
\text { and HP users }\end{array}$ \\
\hline
\end{tabular}


its effect on science learning outcomes in terms of digital literacy (Jayanti, 2019) Science literacy can be trained using Schoology-based e-learning (Misbah et al., 2018). The use of website-based learning media can also improve students' digital literacy skills in learning physics (Rahayu et al., 2019). The applied research that will be carried out also utilizes IT-based learning media (technology).

The learning media used is the Real Science Mask with QR Code, in the form of a mask containing illustrations of science material connected to google classroom. Real Science Mask with QR Code as a learning medium specially designed to improve digital literacy of science students. Research on the use of science masks linked to QR codes has never been conducted. The research activity is divided into 2 stages, namely: 1) making Real Science Mask with QR Code validated by experts and learning tools that have been tested for legibility, 2) testing the use of Real Science Mask with QR Code in learning to see the effectiveness in improving students' digital literacy IPA accompanied by a description of device development.

\section{CONCLUSION}

Media development activities are carried out through expert assessments and revisions. Experts/validators selected in this stage are experts in the field of material and media. Material experts are needed to obtain input regarding the material content presented in learning media. Meanwhile, media experts are needed so that the learning media used can facilitate students in learning. Input from the validators was carried out to revise the Real Science Mask with QR Code. The development of Real Science Mask with QR Code learning media was appropriate based on expert validation and has been tested feasible and valid to improve digital literacy of science students.

\section{ACKNOWLEDGMENT}

This paper and the research behind it would not have been possible without the supporting from Daftar Isian Pelaksanaan Anggaran (DIPA) Universitas Negeri Semarang. Number: SP DIPA-023.17.2.677507/2020, 27th Dec 2019, in Fund Research Implementation Assignment Agreement Letter DIPA UNNES 2020 Number: 292.23.4/UN37/PPK.3.1/2020, 23rd April 2020. The generosity and expertise of one and all have improved this study in innumerable ways and saved me from many errors; those that inevitably remain are entirely my own responsibility.

\section{REFERENCES}

A'yuni, Q. Q. (2015). Literasi digital remaja di kota Surabaya. Journal Unair. Retrieved from http://journal. unair. ac. id/download-fullpapers-ln53e61a7e60full. pdf.

Asyhari, A., \& Silvia, H. (2016). Pengembangan Media Pembelajaran Berupa Buletin dalam Bentuk Buku Saku untuk Pembelajran IPA Terpadu. Jurnal Ilmiah Pendidikan Fisika Al-Biruni, 5(1), 1-13.

Emzir, P. Dr. 2010. Metodologi Penelitian Kualitatif: Analisa Data. Rajawali Pers: Jakarta.

Fatimah, S., \& Mufti, Y. (2014). Pengembangan media pembelajaran IPA-fisika smartphone berbasis android sebagai penguat karakter sains siswa. Jurnal Kaunia, 10(1), 59-64.

Hutagalung, A. M. (2013). Efek model pembelajaran inquiry training berbasis media komputer terhadap keterampilan proses sains dan kemampuan berpikir kritis siswa (Doctoral dissertation, UNIMED)

Jayanti, E. D., Aryana, I. B. P., \& Gunamantha, I. M. (2019). Pengaruh Model Pembelajaran Sains Teknologi Masyarakat Terhadap Hasil Belajar Ipa Ditinjau Dari Literasi Digital Siswa Kelas V Sekolah Dasar Gugus Vi Kecamatan Mengwi. PENDASI: Jurnal Pendidikan Dasar Indonesia, 1(2), 55-64.

Kurniawati, J., \& Baroroh, S. (2016). Literasi Media Digital Mahasiswa Universitas Muhammadiyah Bengkulu. Jurnal Komunikator, 8(2), 51-66.

Mauludin, S., \& Cahyani, I. (2018, November). Literasi Digital Dalam Pembelajaran Menulis. In Seminar Internasional Riksa Bahasa (pp. 12731282).

Misbah, M., Pratama, W. A., Hartini, S., \& Dewantara, D. (2018). Pengembangan e-learning berbasis schoology pada materi impuls dan momentum untuk melatihkan literasi digital. PSEJ (Pancasakti Science Education Journal), 3(2), 109-114.

Mulyadi, D. U., \& Wahyuni, S. (2016). Pengembangan media flash flipbook untuk meningkatkan keterampilan berfikir kreatif siswa dalam pembelajaran IPA di SMP. Jurnal Pembelajaran Fisika, 4(4), 296-301.

Murray, M. C., \& Pérez, J. (2014). Unraveling the digital literacy paradox: How higher education fails at the fourth literacy. Issues in Informing Science and Information Technology, 11, 85.

Nurhcayo, M. A. (2016). Peningkatan Literasi Digital Dan Keterampilan Pemecahan Masalah Siswa Smp Menggunakan Model Pembelajaran Technology-Embedded Scientific Inquiry (Tesi) Pada Materi Struktur Bumi Dan Bencana (Doctoral dissertation, Universitas Pendidikan Indonesia).

Permana, M. S., \& Damiri, D. J. (2014). Pengemban- 
gan Media Pembelajaran Interaktif Ilmu Pengetahuan Alam (IPA) Berbasis Multimedia. Jurnal Algoritma, 11(2), 254-263.

Rahayu, T., Mayasari, T., \& Huriawati, F. (2019). Pengembangan Media Website Hybrid Learning Berbasis Kemampuan Literasi Digital dalam Pembelajaran Fisika. Jurnal Pendidikan Fisika, 7(1), 130-142.

Rahman, A. Z., Hidayat, T. N., \& Yanuttama, I. (2017). Media Pembelajaran IPA Kelas 3 Seko- lah Dasar Menggunakan Teknologi Augmented Reality Berbasis Android. Semnasteknomedia Online, 5(1), 4-6.

Setyaningsih, R., Abdullah, A., Prihantoro, E., \& Hustinawaty, H. (2020). Improving Communication and Collaboration Skills via e-Learning Contents. KOMUNIKA: Jurnal Dakwah dan Komunikasi, 14(2), 213-222. 